\title{
DIGITAL MUSEUM CONSTRUCTION STANDARDS STUDY
}

\author{
Tong Yu, Ma Yinghua \\ Tsinghua Heritage Institute for Digitization Company Limited, D-003, 3/F, Building 1, No.41 West Shangdi Road, Haidian District, \\ Beijing-yutong@thid.cn
}

KEY WORDS: Post-Pandemic Era, digital museums, functionality, digitization, standards, New Form

\begin{abstract}
:
In the post-epidemic era, with the development of digital information technology, there is an extremely urgent need for the construction of digital museums in the field of cultural and museums. However, there is no unified consensus on the concept, function and form of digital museums at home and abroad. The author believes that digital museums are a special form of traditional physical museums and should give full play to digital features and advantages to meet the needs of online and offline integration. This paper is oriented to the practical problems that exist in the realization of the basic functions of traditional physical museums based on collection, management, storage, research, exhibition, education and popularization, and public services. By collating the current standards of digital museums, analyzing the new forms of digital museums domestically and abroad, clarifying the mission of digital museums, proposing the construction and development of digital museums around "human experience", exploring the standards of digital museum construction, and promoting the industry consensus and standardized management of digital museum construction.
\end{abstract}

\section{INTRODUCTION}

The new coronavirus epidemic has caused a serious impact on museums and art galleries around the world, according to statistics, 85,000 museums closed during the epidemic, accounting for nearly $90 \%$ of the total number of museums in the world, of which nearly $13 \%$ may be permanently closed. 5,535 museums were registered in China in 2019, of which $52.92 \%$ of museums in the heritage industry, the largest number . Affected by the epidemic heritage industry museums open social functions significantly reduced, more than $50 \%$ of the heritage industry museums are still stuck in the provision of traditional static display displays, discrete interpretive content, a single service and offline viewing experience approach, offline interpretation of narrative and interactivity is poor.

At present, the common form of performance of digital museums domestically and abroad is to copy the physical museum into web form. The number of digital museums on Baidu.com alone has reached 1609 , accounting for about $30 \%$ of the total number of physical museums nationwide. The number of "cloud exhibitions" held nationwide during the epidemic exceeded 2,000, attracting more than 5 billion visitors with the average number of visitors exceeding 2.5 million. To a certain extent, digital museums have improved the social openness of physical museums, and digital means can achieve both the preservation of cultural relics and the needs of display and dissemination.

With the public's growing demand for high-quality cultural experiences, the demand for exhibition-viewing experiences is also increasingly pursuing storytelling, fun, and creativity, and simple web browsing cannot meet people's exhibition-viewing needs. In the post-epidemic era, as digital technology becomes increasingly mature, various forms of digital creativity are emerging in the field of cultural and museums.

Based on the above issues, this paper systematically compares the development of existing standards related to digital museums in China from the three dimensions of traditional museum construction, digital content presentation, and digital information technology application, as well as the new forms of digital museums emerging at present, and explores the basic ideas of digital museum standards construction. The basic functions, content requirements, and technical index system that digital museums should have are sorted out.

\section{OVERVIEW OF CURRENT STANDARDS RELATED TO DIGITAL MUSEUMS}

\subsection{Museum Dimension}

Cultural relics in the collection registration specifications" (WW/T 0017-2013) provides the main information on the collection of cultural relics in the collection registration process and the required documents (including paper files and electronic files) the basic content and fill out the requirements, including the focus on the total registration number, the level of identification (see the "classification of cultural relics collection standards"), the source, intact condition and other requirements. Apply to the collection of cultural relics unit of heritage registration work. Museum Exhibition Content Design Specification" (WW/T0088-2018) stipulates the principles of museum exhibition content design, the process of design and the specific requirements of each stage, focusing on specific requirements including exhibition selection, preliminary survey, exhibition outline design, exhibit determination, exhibition text determination, etc. Applicable to the content design work of museum exhibitions. Other exhibitions can refer to the implementation. Museum display exhibition form design and construction specifications" (WW/T0089-2018) specifies the work procedures and related technical requirements for the form design, construction production, engineering supervision and project acceptance of museum display exhibitions. Applicable to the design and construction of open exhibits held by museums (museum regulations definition). The design and construction of the exhibition of the interior of the protected buildings and the conservation (ancient buildings, old sites, ruins) buildings at all levels, and the exhibition of non-state museums can be used for reference. The Functional Design Guide for Exhibition Venues (GB/T 34395-2017) gives guidelines for the functional design of exhibition venues in which people and objects are the main flow elements, focusing on the design of the human flow system, vehicle flow system 
and logistics system of offline venues. It is applicable to guide the design of exhibition venues.

\subsection{Digital Content Presentation Dimension}

The Internet Interactive Video Data Format Specification (GYT 332-2020) specifies the data format of Internet interactive video, focusing on interactive video system architecture, interactive component classification and parameter configuration, interactive video data format, etc. Applicable to the construction, operation and maintenance of the Internet interactive video system, as well as the production, exchange, distribution and playback of content. High-definition television sound identification and calibration signal technical requirements" (GYT 331-2020) specifies the high-definition television program production and broadcasting, transmission link testing in the need for audio identification and calibration signal technical requirements, including stereo, surround sound identification and calibration signal and other technical requirements. Applicable to the production, exchange, broadcast and transmission of high-definition television programs. Ultra High Definition Television System Program Production and Exchange Parameter Values" (GYT 307-2017) specifies the basic parameter values involved in Ultra High Definition Television (UHDTV) system program production and exchange. It applies to UHDTV program production and program exchange, and also applies to the design, production, acceptance, operation and maintenance of UHDTV systems and equipment.

\subsection{Digital Information Technology Standard Dimension}

The "Technical Regulations for Three-Dimensional Information Acquisition of Cultural Relics Buildings" (DB11/T 1796-2020) stipulates the technical requirements for three-dimensional information acquisition operations of cultural relics buildings in terms of technical preparation, control measurement, data acquisition and processing, results production, quality inspection and archiving of results. Applicable to the threedimensional information collection operations of heritage buildings. Historical buildings can refer to the implementation. Digital processing of content resources Part 6: Application mode" (GB/T 38548.6-2020) specifies the application mode of digital processing of content resources for long-term preservation and publication-oriented services. It applies to the application of digital processing results of content resources. Specifications for Digitization Processing of Library Collection Resources Part 2: Text Resources" (GB/T 31219.2-2014) specifies the technical standards followed in the digitization processing of library text resources, focusing on including text as the main form of expression, which can exist less is the digitization processing of text documents (excluding special documents such as ancient books and beautiful books, manuscripts, etc.). Applicable to the digitization of library text resources processing. Other documentary information institutions can also refer to the digital processing of text resources. The Specification for Digital Processing of Library Resources Part 3: Image Resources (GB/T 31219.3-2014) gives the processing standards and work specifications for digital resources of image collections, focusing on non-digital information resources stored in different forms and carriers, native digital image resources that exist in the form of digital images when they are first generated, and digital image resources derived from documents after digital processing. Digital image resources derived from digitized documents. This applies to the digital processing of image resources in libraries. The digital processing of image resources of other documentary information institutions can be used with reference. The Specification for Digitization of Library Resources Part 4: Audio Resources (GB/T 31219.4-2014) stipulates the technical parameters and basic work specifications for the digitization of audio resources, including the processing level and technical parameters, processing preparation, acquisition and processing, metadata processing, naming rules, and quality management for the digitization of audio resources. It applies to the digital processing of audio resources in libraries. The digital processing of audio resources of other documentary information institutions can also be used with reference. The Specification for Digitization and Processing of Library Resources Part 5: Video Resources (GB/T 31219.5-2016) stipulates the workflow of video digitization and processing, metadata standards for content marking, and naming rules for video digital objects. It is applicable to libraries at all levels and of all types nationwide in the acquisition, coding conversion, preservation and editing of analog video, digital video and network video. It can also be used for reference by institutions engaged in publishing, teaching, scientific research and other related businesses. Information Technology Basic Requirements and Test Methods for Virtual Reality Application Software (GB/T 38258-2019) specifies the basic requirements for virtual reality application software and test methods. It is applicable to the performance design, development and performance testing of virtual reality application software. Information Technology General Specification for Virtual Reality Head-mounted Display Devices (GB/T 38259-2019) specifies the classification, basic requirements, test methods, inspection rules and markings, packaging, transportation and storage of virtual reality headmounted display devices. Applicable to the design, manufacture, inspection, testing and application of virtual reality headmounted display devices. The Technical Regulations for Virtual Reality Imaging (DB22/T 3047-2019) specifies the technical requirements for virtual reality imaging, virtual reality equipment and experience requirements. It applies to the whole process of producing content for virtual reality products. The General Technical Requirements for Mobile Augmented Reality Business Capability (YD/T 3078-2016) specifies the system architecture of mobile augmented reality (MobAR). The overall technical requirements for business capabilities in terms of component functions, message processes, interface protocol bindings, etc. that need to be supported by the MobAR system are formulated. It is applicable to intelligent terminals and application servers in the mobile Internet business environment.

\section{NEW FORMS OF DIGITAL MUSEUMS DOMESTICALLY AND ABROAD}

\subsection{Web Portal for Museums}

The Palace Museum website page design, display content is simple and clear, its main functional modules include: guide, exhibition, education, exploration, academic, cultural and creative, about 7 functional modules. The Palace Museum website has been considered a more comprehensive and content-rich representative of the museum portal, its online collections, educational materials, cultural and creative derivatives and other activities have a solid content base, and for the basic functions of the museum has also completed a more comprehensive implementation. 

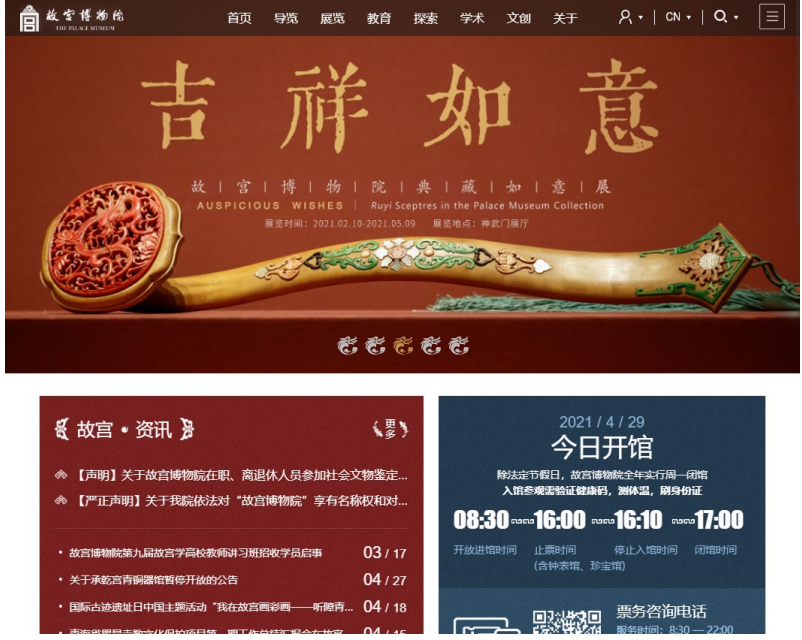

Figure 1. The Palace Museum home page interface.

A sample of three elements for the video gallery, the Palace Museum APP and the panoramic Forbidden City: (1)the Palace Museum video gallery has a total of 100 video content. The highest number of individual videos played 15,900 times, the lowest number of plays only 9 times, and the vast majority of videos played less than a thousand, only 5 videos played tens of thousands. This shows that the video gallery user participation is low. (2) Palace Museum APP a total of 10, in the Palace Museum website shows that all can be downloaded in the Apple App store, of which 4 can also be downloaded in Android. Using the Apple App store search, only 5 of the APP can be found, a total of 4457 evaluation information, a single APP up to 2561 evaluation information, the least 83 evaluation information. This shows that the Palace Museum APP user volume is low. (3)panoramic view of the Forbidden City likes feedback a total of more than 190,000 times, compared to the number of web page views, the number of likes is low. In summary, the results of the survey, the Palace Museum website is more complete, but the comprehensive application rate is relatively low.

\subsection{Panoramic Cloud Tour}

The form of panoramic cloud tour has been widely used in museum online display, typical cases include: cloud tour of the Forbidden City, the National Museum of China digital exhibition hall, digital Dunhuang Museum, etc.. Through panoramic photography of the museum's real scene, the panoramic photos are specially assembled and processed, combined with page navigation functions and voice narration, etc., to imitate the physical museum tour experience.

\subsection{Cloud Showroom}

There are various forms of cloud exhibition hall, including 2.5D cloud exhibition hall and 3D cloud exhibition hall. 2.5D cloud exhibition hall takes the graduation exhibition of Academy of Fine Arts of Tsinghua University as a typical case. It can clearly divide multiple booths according to different display themes, and each booth can be divided into multi-layer pages such as vision, mid-view and close-up to carry out the design, and the horizontal tour of each booth has an obvious sense of hierarchy. Although its display content is limited to two-dimensional elements such as text, pictures, audio and video, it effectively enhances the fun and beauty of traditional page browsing. 3D cloud exhibition hall takes Da Vinci Technology Special
Exhibition as a typical case. It builds a virtual scene model through 3D digital technology, and completes the online tour in the way of panoramic guide. Its display content not only contains two-dimensional elements such as text, pictures, audio and video, but also contains 3D digital models, creating an online 3D tour experience of the virtual digital world.

\subsection{Offline Interactive Digital Creativity}

The Cleveland Museum of Art in the United States had won the Brand New Groundbreaking Award for ArtLens Studio, which opened in June 2016. This project contains interactive features such as portrait making, digital collage, and painting games, and the public can experience the fun of art creation through interactive games, which are highly interesting and popular among the public. In recent years, immersive exhibition has become one of the main ways to display art, with the immersive exhibition works of TeamLab team in Japan being the most representative. Through digital presentation technology, immersive interactive scenes are created without the use of wearable devices. The immersive exhibition format puts people in the scene and gives them an immersive and stunning experience through multi-sensory, interactive displays. The immersive exhibition designed by TeamLab has been named as one of the "Top 10 Must-See Art Exhibitions in the World" and "A Technological Wonderland of Dreams", and has been widely acclaimed by audiences worldwide.

\subsection{Digital Museum 2.0}

$\mathrm{RE}$ - International Center for Digital Creativity was opened in Beijing in July 2020, as the world's first immersive interactive experience museum with "cultural heritage - digital creativity" as its core, it integrates $\mathrm{VR} / \mathrm{AR}$ interactive experience and introduces online and offline science education products and rich Cultural and creative derivatives. The outstanding achievements of RE - International Center for Digital Creativity in the construction of new forms of digital museums have been unanimously recognized by many experts. The digital exhibitions and educational activities hosted by it have also been well received by the general public. The author believes that RE - International Center for Digital Creativity can be called the digital museum 2.0 form

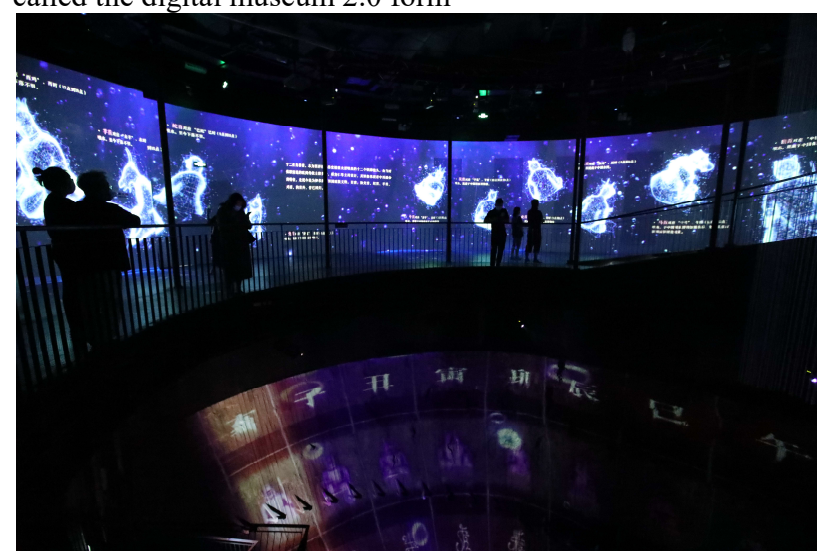

Figure 2. RE - International Center for Digital Creativity 1-1. 


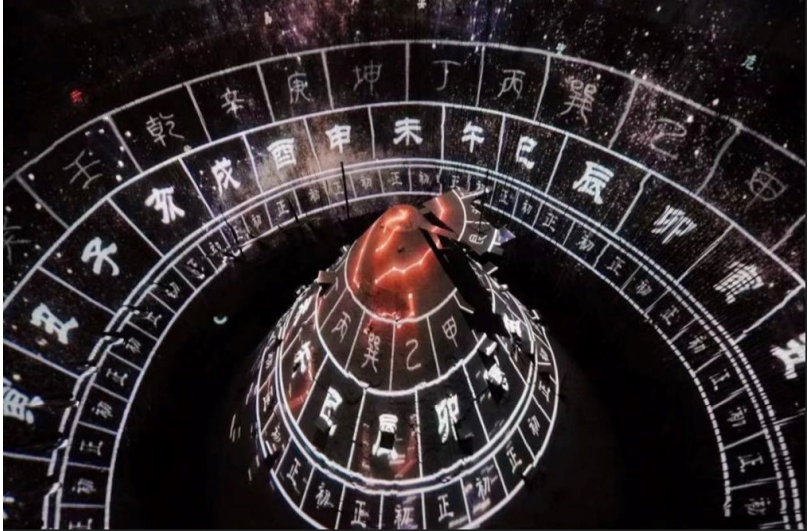

Figure 3. RE - International Center for Digital Creativity 1-2.

\subsection{Comprehensive evaluation}

The museum portal has taken the form of a digital museum, with more complete basic functional elements and a higher degree of realization of internal functions. The Palace Museum is characterized by a high comprehensiveness of cultural relics and a large number of collections. On this basis, it has a rich variety of related digital derivative products, such as educational videos, online mini-games, mobile apps, and related cultural activities. The disadvantage embodied by the museum portal is the poor realization of external functions. The data analysis shows that human participation is low and the rich digital function modules fail to play their value well. The digital museum should realize the basic functions and at the same time, it should start from the human experience, enhance the human involvement, and finally serve the public effectively, so as to reflect the meaning of the existence of the digital museum.

A large number of museums have integrated the panoramic cloud tour format as an important display module of their portals. Compared with the direct browsing of web pages with graphics and audio and video, the experience of the panoramic cloud tour has a certain innovative form. Visitors can choose their own tour route, tour order, and viewing focus, which is somewhat interactive. The disadvantage of this experience form is that it lacks creativity and interest, and is still mainly based on replicating the offline venues. Therefore, the majority of people who are not constrained by the conditions still prefer to visit the field. Most of those who participate in online tours are still aiming at "form experience", and rarely can complete all the online content tours.

Compared with the panoramic cloud tour form, the cloud exhibition hall has a certain improvement in creativity. Both the 2.5D cloud exhibition hall and 3D cloud exhibition hall pay much attention to the exhibition planning and exhibition design of the virtual exhibition hall. The virtual exhibition hall can give full play to the lightweight advantages of digital information technology and design into a variety of exhibition designs that are difficult to achieve in physical museums such as artistic, stylized, and exaggerated generations. Subtle design can bring freshness and thus enhance the interest of online tours.

"ArtLens Studio" and teamLab's immersive exhibitions are offline digital experiences. Compared with various online forms, their greatest advantage is that they greatly satisfy the public experience. Both of them are highly creative and can fully attract public participation. ArtLens Studio's rich interactive experience program is highly interesting, allowing visitors to transform from "visitors" to "creators" and deeply experience the beauty of art. The multi-sensory and interactive exhibition format of the immersive exhibition can drive the change of human emotions and build the connection between people and content, thus upgrading the experience.

RE - International Center for Digital Creativity can be regarded as the digital museum 2.0 form, which further realizes the online and offline integration form of digital museum. Its advantage is that (1) it can give good play to the advantages of digital creativity and make digital information technology properly applied to museum display. Through digital creativity to attract public attention and participation, rich interactive forms to enhance the public experience. (2) The content arrangement is innovative, combined with narrative research is easier for the audience to understand. High requirements for content production, with original IP awareness. (3) Form an integrated online and offline form, giving full play to the advantages of online content extension and promotion, offline heavy experience and strong interaction.

\begin{tabular}{|c|c|c|c|}
\hline Form & Typical cases & Advantages & Disadvantages \\
\hline $\begin{array}{l}\text { Museum } \\
\text { Portal }\end{array}$ & $\begin{array}{c}\text { The Palace } \\
\text { Museum website }\end{array}$ & $\begin{array}{l}\text { 1.Perfect function } \\
\text { 2. Rich content } \\
\text { 3. Various forms } \\
\text { 4. Wide range of } \\
\text { dissemination }\end{array}$ & $\begin{array}{l}\text { 1. Low } \\
\text { utilization rate } \\
\text { 2.Poor } \\
\text { experience }\end{array}$ \\
\hline $\begin{array}{l}\text { Panoramic } \\
\text { Cloud Tour }\end{array}$ & $\begin{array}{l}\text { Cloud tour of the } \\
\text { Forbidden City, } \\
\text { The National } \\
\text { Museum of } \\
\text { China digital } \\
\text { exhibition hall, } \\
\text { Digital } \\
\text { Dunhuang } \\
\text { Museum, }\end{array}$ & $\begin{array}{l}\text { 1. Online } \\
\text { interaction } \\
\text { 2.Wide } \\
\text { dissemination }\end{array}$ & $\begin{array}{l}\text { 1.Copy offline } \\
\text { 2. Low } \\
\text { utilization rate } \\
\text { 3.Poor } \\
\text { experience }\end{array}$ \\
\hline $\begin{array}{c}\text { Cloud } \\
\text { Showroom }\end{array}$ & $\begin{array}{l}\text { The graduation } \\
\text { exhibition of } \\
\text { Academy of Fine } \\
\text { Arts of Tsinghua } \\
\text { University, } \\
\text { Da Vinci } \\
\text { Technology } \\
\text { Special } \\
\text { Exhibition } \\
\end{array}$ & $\begin{array}{l}\text { 1. Online } \\
\text { interaction } \\
\text { 2. Rich in content } \\
\text { 3. Aesthetically } \\
\text { pleasing } \\
\text { 4. Wide } \\
\text { dissemination }\end{array}$ & $\begin{array}{l}\text { 1. Low } \\
\text { utilization rate } \\
\text { 2. General } \\
\text { experience }\end{array}$ \\
\hline $\begin{array}{c}\text { Offline } \\
\text { Interactive } \\
\text { Digital } \\
\text { Creativity }\end{array}$ & $\begin{array}{c}\text { ArtLens Studio } \\
\text { The immersive } \\
\text { exhibition } \\
\text { works of } \\
\text { TeamLab }\end{array}$ & $\begin{array}{l}\text { 1.Offline } \\
\text { interaction } \\
\text { 2. Highly creative } \\
\text { 3. Excellent } \\
\text { experience }\end{array}$ & $\begin{array}{l}\text { 1. Less content } \\
\text { of science } \\
\text { education } \\
\text { 2. Limited } \\
\text { dissemination } \\
\text { scope }\end{array}$ \\
\hline $\begin{array}{l}\text { Digital } \\
\text { Museum } \\
2.0\end{array}$ & $\begin{array}{c}\text { RE - } \\
\text { International } \\
\text { Center for } \\
\text { Digital } \\
\text { Creativity }\end{array}$ & $\begin{array}{l}\text { 1.Perfect function } \\
\text { 2.Online+offline } \\
\text { interaction } \\
\text { 3. Rich content } \\
\text { 4. Various forms } \\
\text { 5. High } \\
\text { participation } \\
\text { 6. Excellent } \\
\text { experience }\end{array}$ & $\begin{array}{l}\text { 1. Online and } \\
\text { offline } \\
\text { integration form } \\
\text { is not yet } \\
\text { mature }\end{array}$ \\
\hline
\end{tabular}

Table 1. Analysis of new forms of various digital museums.

Digital creative forms are rich and diverse. The online form can give full play to the lightweight advantages of digitalization, which is easy to store, access, study and research the massive content. The use of the Internet can widely promote digital content, and Internet dissemination is subject to time, location, climate, environment and other objective factors is very small, can effectively expand the scope of the audience. Offline digital creative experience forms often have obvious advantages in creativity, fun, interactivity, and a strong sense of comprehensive experience far beyond the online experience. Therefore, the construction of digital museums should design the content and technical system of online and offline 
integration, play the advantages of online and offline, and form a new form of online and offline integration of digital museums.

\section{FUNCTIONAL REQUIREMENTS FOR THE CONSTRUCTION OF NEW FORMS OF DIGITAL MUSEUMS}

\subsection{Combing the basic functional elements of traditional museums}

In 1956, the National Conference on Museum Work for the first time clearly defined the social status and role of museums: museums are "organs of scientific research," "organs of culture and education," and "collections of material and spiritual cultural relics and natural specimens. It is generally believed that the basic functions of museums are collection, organization, storage, research, exhibition, education and popularization and public services. According to the service objects of each function, the above seven basic functions can be roughly divided into two categories. The first category is for the internal functions of cultural relics, including collection, organization, storage, and research. The second category is the publicoriented external functions, including exhibitions, education and popularization and public services .

The following is an interpretation of the basic functional characteristics of traditional museums, as well as an analysis of existing problems:

\begin{tabular}{|c|c|c|}
\hline Functions & Meanings & issues \\
\hline Collection & $\begin{array}{l}\text { Collecting and storing } \\
\text { collections }\end{array}$ & $\begin{array}{l}\text { Uncertainty in the collection } \\
\text { process; large space } \\
\text { requirements for physical } \\
\text { collection storage }\end{array}$ \\
\hline Sorting & $\begin{array}{l}\text { Labelling, classification } \\
\text { and information } \\
\text { gathering of collections }\end{array}$ & $\begin{array}{l}\text { High management costs due to } \\
\text { the need for professional staff } \\
\text { to carry out the finishing work }\end{array}$ \\
\hline Safekeeping & $\begin{array}{l}\text { Conservation and } \\
\text { management of the } \\
\text { collection }\end{array}$ & $\begin{array}{l}\text { The conservation requirements } \\
\text { for different types of } \\
\text { collections vary, and if not } \\
\text { properly protected, the } \\
\text { physical objects are more } \\
\text { difficult to restore and more } \\
\text { costly to manage }\end{array}$ \\
\hline Research & $\begin{array}{l}\text { Conducting extensive, } \\
\text { systematic and iterative } \\
\text { exploration of the } \\
\text { collection }\end{array}$ & $\begin{array}{l}\text { For physical collections and } \\
\text { materials, there is } \\
\text { inconvenience in searching (as } \\
\text { opposed to data searching) }\end{array}$ \\
\hline Exhibition & $\begin{array}{l}\text { Public display of the } \\
\text { collection for the } \\
\text { purpose of public } \\
\text { viewing, in accordance } \\
\text { with certain } \\
\text { requirements }\end{array}$ & \multirow{2}{*}{$\begin{array}{l}\text { The integrity of the physical } \\
\text { collection varies greatly; the } \\
\text { higher the conservation } \\
\text { requirements of the physical } \\
\text { collection, the greater the } \\
\text { negative impact on the display } \\
\text { effect; compared to digital } \\
\text { display, the exhibition format } \\
\text { is more homogeneous and the } \\
\text { intuitiveness is limited; subject } \\
\text { to time, location, } \\
\text { environmental conditions and } \\
\text { other objective factors }\end{array}$} \\
\hline Education & $\begin{array}{l}\text { The use of physical } \\
\text { objects as a vehicle for } \\
\text { the dissemination of } \\
\text { culture, knowledge, } \\
\text { ideas and ethics to the } \\
\text { human senses }\end{array}$ & \\
\hline $\begin{array}{l}\text { Public } \\
\text { Services }\end{array}$ & $\begin{array}{l}\text { To provide recreational } \\
\text { tours, viewing and } \\
\text { entertainment for the } \\
\text { public }\end{array}$ & Lack of fun \\
\hline
\end{tabular}

Table 2. Functional analysis of traditional museums.

The above-mentioned issues of the functional characteristics of traditional museums, summarized according to internal functions, and external functions, can be grouped into the following points:

\begin{tabular}{|c|c|c|}
\hline Categories & Main issues & Details \\
\hline \multirow{9}{*}{$\begin{array}{l}\text { Internal } \\
\text { functions }\end{array}$} & \multirow{3}{*}{$\begin{array}{l}\text { Comprehensiveness } \\
\text { of the collection }\end{array}$} & Vanishing Collection \\
\hline & & Fragmentary collection \\
\hline & & Lost Collection \\
\hline & \multirow{3}{*}{$\begin{array}{l}\text { Conservation of the } \\
\text { collection }\end{array}$} & A wide range of collections \\
\hline & & Harsh protection conditions \\
\hline & & Damage not easily recovered \\
\hline & \multirow{3}{*}{$\begin{array}{l}\text { Collection } \\
\text { Information } \\
\text { Management }\end{array}$} & A wealth of information \\
\hline & & $\begin{array}{c}\text { Cumbersome information } \\
\text { network }\end{array}$ \\
\hline & & Higher management costs \\
\hline \multirow{3}{*}{$\begin{array}{l}\text { External } \\
\text { functions }\end{array}$} & \multirow{3}{*}{$\begin{array}{l}\text { Exhibition display } \\
\text { and experience } \\
\text { enhancement }\end{array}$} & $\begin{array}{l}\text { There is a conflict between the } \\
\text { conservation requirements of the } \\
\text { physical collection and the } \\
\text { exhibition and display }\end{array}$ \\
\hline & & $\begin{array}{c}\text { Direct display is heavily } \\
\text { influenced by objective factors }\end{array}$ \\
\hline & & $\begin{array}{l}\text { Single means of presentation, } \\
\text { experience needs to be upgraded }\end{array}$ \\
\hline
\end{tabular}

Table 3. Summary of main issues.

\subsection{Digital Information Technology Applications}

\subsubsection{Digital Museum Definition}

A digital museum is defined as a museum that uses information technology to digitally represent the functions of a traditional physical museum and to share the resources of cultural objects on the Internet. Digital museums are also museums, compared to physical museums, digital museums are the digital form of museums. Therefore, digital museums should meet the functional requirements of museums. At the same time, the main significance of digital museums is to bring into play the advantages of digital technology tools and propose solutions to the drawbacks of traditional museums with physical collections as the core in functional realization, so as to achieve functional complementarity.

3.2.2 Digital technology solves the problem of collection comprehensiveness

Only a very small percentage of collections and artifacts have survived from their respective eras and are in good condition and in museum collections. A large number of collections and artifacts are in various degrees of disrepair, or have even disappeared completely. There are also some collections and artifacts that exist but are difficult to be collected by museums because of their unknown destination, such as the unreturned heads of the "Twelve Heads of Beasts" from the Yuanmingyuan. For the above three types of difficult-to-acquire collections and cultural relics, we can obtain relevant information through archaeological exploration and historical research, and then use digital recovery technology to obtain highly accurate digital 3D models. For the existing well-preserved collections and cultural relics, 3D scanning and point cloud data collection technologies can be used to complete the modeling. Through the above technologies, we can effectively enhance the comprehensiveness of the collection.

Collections and cultural relics are important witnesses of history, based on historical authenticity, digital restoration technology should be standardized requirements to ensure that information sources are standardized and reliable, should be strictly controlled (including but not limited to) the authenticity, accuracy, authority and legality of the information sources. 
3.2.3 Digital technology solves collection conservation problems

Collections and cultural relics are diverse and can be subdivided into many categories according to material, function, properties, origin, and value. Different types of collections and cultural relics have different conservation requirements. The protection conditions for the body of collections and cultural relics are generally harsh, especially for the higher value and fragile collections and cultural relics. Once damaged, it is difficult to restore them to their original state, which will bring great losses to the country and human society. The digitization of collections and cultural relics is itself a means of protection of cultural relics, and digital collections are damaged (i.e., data damage), i.e., data repair, or even reconstruction of digital collections. In addition, the establishment of a standardized database for storage and standardized management can effectively avoid data damage and loss, thereby effectively protecting digital collections.

3.2.4 Digital technology solves collection data management challenges

Collections and cultural relics themselves have historical value, cultural value and research value, and they contain rich information resources, and historical records, archaeological reports, etc. are linked by different information chains. Moreover, there may be information links between different collections and cultural relics. As a result, a huge amount of information will be generated, and the information network built therein is even more complicated, bringing inconvenience to information management and scientific research. Nowadays, in the era of big data, data processing technology is changing rapidly. The application of data cleaning, visual analysis, data annotation, hierarchical management, construction of knowledge graphs and other related technologies can comprehensively integrate, quantify, retrieve and export data, effectively improve the level of collection information management and provide more convenient conditions for scientific research in museums.

3.2.5 Digital technology solves exhibition display problems to enhance the human experience

There is a contradiction between the protection requirements of physical collections and exhibition and display. The higher the conservation requirements of physical collections, the greater the restrictions on display, the worse the display effect, and the more conservative means of exhibition, resulting in a single form of exhibition, intuition is limited, it is difficult to meet the needs of the public viewing experience. Under the influence of the global epidemic, the traditional museum exhibition display by objective factors revealed the problem, time, place, environment and other social factors on its restrictions have become an important issue for a long time. Today's digital display technology is developing rapidly, with virtual reality and augmented reality technology, $8 \mathrm{~K}$ ultra-high definition technology, immersive digital viewing technology, cloud relay and panoramic technology all serving to enhance the human experience, while in today's Internet era, the rapid development of $5 \mathrm{G}$ environment provides a solid foundation for online communication. All the above technologies can be applied to the exhibition display of digital museums, and continuous exploration and experimentation are still needed to finally achieve the enhancement of human experience.

\subsection{Digital Information Technology Applications}

The digital museum only stays at the stage of complete basic functions, and it is difficult to effectively drive the degree of public participation, even though the external exhibition, education and public services are fully functional, but fails to realize the meaning of its functional setting existence. As a museum, only the collection, arrangement, storage, and research of cultural relics specimens can not be called a complete museum, but only as a depository, archive, archaeological or cultural research institute. Therefore, the construction of digital museums should focus on human experience, give full play to the advantages of digital information technology, and carry out innovative design of digital exhibition forms and comprehensive exhibition design, so as to enhance public experience and make the public willing to actively participate, thus realizing the mission and construction significance of digital museums.

Based on the basic functions of the digital museum, around the online and offline integration form, integrated digital content and digital information technology system, the preliminary proposal of the new form of digital museum construction system. The choice of each basic function implementation method should highlight the advantages of online and offline integration. The content and technology system is not limited to the current situation, and should be constantly iterated and innovated with the development of technology. The direction of iterative innovation of digital content and digital information technology system can be distilled into three points: (1)Experience form innovation: innovative experience form design can stimulate public curiosity and attract public participation. (2) Strong interaction: the use of digital information technology to strengthen interaction can effectively enhance the public experience. (3)Integration of online and offline: strengthen the digital construction of offline, and the digital experience form of offline is more diversified, more content and better effect, so as to give play to the advantages of offline experience; integrate the advantages of online content extension and promotion, and form the integration of online and offline participation methods. 


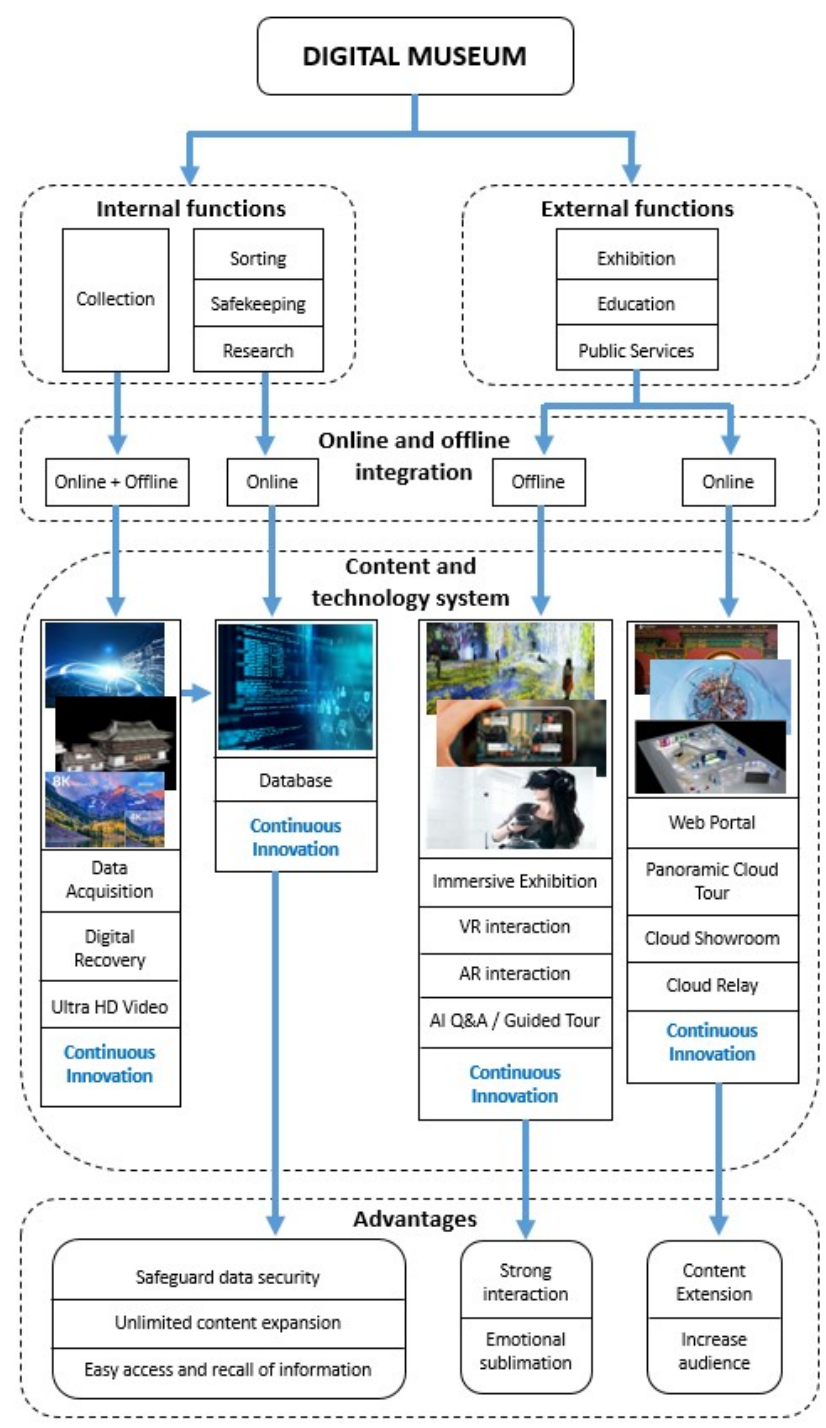

Figure 4. New form of digital museum construction system.

\section{SUMMARY}

This paper considers the development trend of the museum industry in the context of the post-epidemic era, focusing on the construction of new forms of digital museums as the core of the research. Firstly, the author systematically compares the development of existing standards related to digital museums in China from three dimensions: traditional museum construction, digital content presentation and digital information technology application, and presents the main roles, relevance and applicability of each existing standard. Secondly, we analyze the new forms of digital museums domestically and abroad, and put forward the view of "online and offline integration". Finally, from the basic functions of museums, we study the advantages of digital information technology applications and preliminarily propose a new form of digital museum construction system that integrates online and offline. In this paper, we redefine the concept of digital museum as a new form of digital museum development in the context of digital information era, and guide the application of digital information technology in the way of online and offline integration, so as to bring out the greater value of museums to human society.

Digital museums should make use of digital technology to compensate for the shortcomings of traditional museums in terms of functional realization. It should focus on the "human experience", take advantage of "experience innovation" and "experience upgrade", and focus on enhancing the external functions of the museum to serve the public. The digital museum is a product of the integration of digital information technology and the field of culture and museums. The stunning display effect is the integration of technology into the content, rather than "show-off", does not lie in the amount of technical content, but to apply the technology to the right, the digital museum display content, including history, art, cultural heritage, the integration of fragmented technology together, so that users understand the display content, is successful. Online and offline integration is not a simple copy, should do online and offline advantages of complementarity. Online through the Internet to strengthen publicity, from time and space to expand the scope of the core content of the display, drive offline participation, offline to strengthen the experience to enhance the public participation enthusiasm, drive more online content and derivative products to expand, so as to generate more public benefits. To expand the impact of the basic functions of the museum in this iteration. Digital museum construction standards need to be constantly explored to verify theories through practice and achieve iterative innovation. The new form of digital museums will gradually become the "new infrastructure construction", adding color to the future development of smart cities.

\section{REFERENCES}

Xinmin Evening News., May 21, 2020 : Nearly 13\% of museums worldwide may close permanently due to the epidemic. https://baijiahao.baidu.com/s?id=1667254223676677999\&wfr= spider\&for $=$ pc.

Qianzhan Industry Research Institute., August 17, 2020: Market analysis of China's museum industry in 2020. https://www.sohu.com/a/413486662_114835.

Junling,W.,2013. Specification for registration of cultural relics in the collection of cultural institutions. WW/T 0017-2013. National Cultural Heritage Administration

Liang, G., 2018. Standards for content development of museum exhibitions. WW/T0088-2018. National Cultural Heritage Administration.

Xiangdong,D., 2020. Specification of data format for interactive video over the internet. GYT 332-2020. National Radio and Television Administration.

Tao, Z., 2020. Ttechnical specification of three-dimensional information acquisition of heritage buildings. DB11/T 17962020. Beijing Municipal Bureau of market supervision and Administration.

The Palace Museum [EB/OL]., April 29, 2021. https: // www. dpm. org. cn/ Home.html.

Ke,Q., June 15, 2017: What kind of digital technology are museums abroad keen on. Cultural and Museum Circle. https://www.sohu.com/a/149189089_740486.

Jiansong, L., 2019: Museum Exhibition Planning: Concepts and Practices. Fudan University Press. 
The International Archives of the Photogrammetry, Remote Sensing and Spatial Information Sciences, Volume XLVI-M-1-2021 28th CIPA Symposium “Great Learning \& Digital Emotion”, 28 August-1 September 2021, Beijing, China

CNCTST., 2018: Chinese Terms in Computer Science and Technology. Science Press. 